\title{
MENALAR POSISI ELIT DAERAH DI ERA DEMOKRASI DAN OTONOMI DAERAH
}

\author{
Hanantyo Sri Nugroho \\ Program Studi Ilmu Pemerintahan, FES Universitas AMIKOM Yogyakarta \\ Email: \\ hanantyosrinugroho@amikom.ac.id
}

\begin{abstract}
Amid the diverse capacities of local governments in exercising their authority in the era of democracy and regional autonomy, local elites have emerged in the regions. The consequences of the emergence of local elites in the region then gave rise to obstacles in democracy, such as political dynasties as well as conflicts related to control of resources, while the rotational dimensions of power and the welfare of the community began to be marginalized. This can be seen from the strengthening of local strongmen and local bossism. This certainly makes the paradigm confusion associated with local elites and local conflicts that occur in the local post-democratic and regional autonomy regions. As it is known that when the regions have not implemented local autonomy and democracy, what happens is that local elites tend to derivate from national politics so that in the event of local conflict the resolution of the conflict can be more easily resolved. Therefore, it is necessary to return to reasoning to redefine the position of the local elite as a central representation as well as a representation of the local community. This research is qualitative using deskresearch. The results show that with local democracy and regional autonomy the spread of political forces makes the formation of local elites that are formed today is centrifugal.
\end{abstract}

Key words: Local Democracy; Regional Autonomy; Local Elite; Conflict.

\section{PENDAHULUAN}

Tulisan ini hendak memberikan gambaran mengenai elit lokal di daerah setelah adanya demokrasi lokal dan juga otonomi daerah.Permasalahan ini menarik untuk dikaji karena semakin terbukanya ruang perebutan antar aktor di tingkat daerah untuk menjadi elit daerah. Sangatlah ironis jika kita ingat bahwa, menjadi elit lokal tidak hanya kemudian berakhir kepada unipolar, tetapi keterbukaan ini akan melahirkan multipolar dan juga sentrifugal. Hal ini yang kemudian berakibat pada semakin sering terjadi perebutan kekuasaan hingga kepada sulitnya cara mengatasi konflik di daerah. Penelitian ini bersifat kualitatif-deskriptif dengan menggunakan desk-research. Kajian akan dibatasi pada dinamika konflik dalam menjadi elit lokal di era demokrasi dan otonomi daerah.

Transisi mengubah dinamika politik lokal di daerah. Hal ini tidak terlepas dari dibukanya ruang bagi elit lokal untuk menunjukkan eksistensi dalam berkuasa di daerah. Telah banyak kajian mengenai orang kuat lokal. Orang kuat lokal diidentikan dengan aktor yang diluar pemerintahan namun dapat mempengaruhi keberlangsungan penyelenggaraan pemerintah. Selain itu, orang kuat lokal juga dapat diidentikandengan orang kuat lokal yang tercipta akibat dari kekuasaan yang didapat saat sedang atau sesudah menjalankan pemerintahan di daerah. Kedua kutub tersebut yang kemudian seringkali digunakan untuk membingkai fenomena politik lokal, maupun elit lokal secara khusus.

Dalam beberapa literature, kemunculan elit lokal di daerah setelah reformasi membawa kekhawatiran terhadap keberlangsungan demokrasi. Pertama, konsekuensi yang muncul dari adanya kemunculan orang kuat lokal di daerah 
setelah reformasi adalah terciptanya dinasti politik. Selain itu, kekhawatiran tersebut juga muncul terhadap penguasaan sumber daya ekonomi dan sosial yang dimonopoli.Tentunya, hal tersebut tidak sesuai dengan semangat dari demokrasi lokal dan otonomi daerah.Demokrasi lokal dan otonomi daerah dimaksudkan memberikan kewenangan agar daerah dapat mengatur maupun mengurus dirinya sendiri, sehingga hal tersebut dapat menghadirkan kesejahteraan bagi masyarakat yang ada di daerah tersebut.

Dinasti politik merupakan transformasi orang kuat lokal untuk berkuasa di era demokrasi, desentralisasi, dan otonomi daerah. Dalam transformasi tersebut, para orang kuat lokal kemudian ikut berpartisipasi menjadi kepala daerah melalui pemilihan daerah secara langsung. Keikutsertaan para orang kuat lokal ini kemudian bergerak pada ranah mobilisasi pemilih, penyelenggaraan pemerintahan, hingga memandulkan pengawasan pemerintahan. Hal tersebut yang kemudian melanggengkan kekuasaan orang kuat lokal tersebut kepada kelompok maupun keluarganya, dimana terkait dengan suksesi atau perpindahan kekuasaan.

Lebih lanjut, terdapat pula argumen bahwa elit lokal terbentuk dari bukan orang kuat lokal namun pernah menjadi penguasa, dimana sebagai kepala pemerintahan, kemudian bertransformasi menjadi orang kuat lokal. Hal ini seringkali didefinisikan dengan "raja-raja kecil" di daerah. Mereka membangun moda sosial mereka melalui kekuasaan yang dimiliki pada saat memerintah. Kekuasaan yang dimiliki dimanfaatkan untuk membangun hingga menguasai sumber daya, seperti ekonomi, politik dan sosial. Hal tersebut dapat tercipta dikarenakan adanya kekosongan "penguasa" yang ada di daerah.Namun, hal tersebut dapat menimbulkan konflik saat ruang tersebut sudah terisi oleh orang kuat lokal yang telah ada.

Perebutan ruang sebagai elit daerah kemudian menarik untuk dikaji.Oleh karena, terdapat beberapa hal ini tentunya membuat kesimpangsiuran paradigma terkait dengan elit lokal dan konflik lokal yang terjadi pada di daerah setelah adanya demokrasi lokal dan otonomi daerah.Sebagaimana diketahui bahwa saat daerah belum melaksanakan otonomi dan demokrasi lokal, maka yang terjadi adalah elit lokal cenderung derivasi dari politik nasional sehingga pada saat terjadi konflik lokal maka penyelesaian konflik dapat lebih mudah terselesaikan.Akan tetapi, hal tersebut tentunya tidak dapat digeneralisasikan mengingat terdapatnya keterbukaan ruang dan aktor sehingga kekuasaan dan konflik cenderung untuk tidak lagi terpusat.

\section{KAJIAN PUSTAKA}

\section{Desentralisasi dan Otonomi Daerah : Awal Perubahan dan Perseteruan}

Secara umum desentralisasi dapat dimaknai sebagai pendelegasian kekuasaan dari pemerintah pusat ke pemerintah daerah.Lebih lanjut, desentralisasi adalah pemindahan wewenang perencanaan, pembuatan keputusan, dan admnisitrasi dari pemerintah pusat kepada organisasiorganisasi lapangannya, unit-unit pemerintah daerah, organisasi-organisasi semi otonom, pemerintah daerah dan non pemerintah daerah (Koirudin, 2005). Pernyataan tersebut kemudian diperkuat dengan penjelasan bahwa desentralisasi dapat dilakukan dalam empat bentuk, yaitu:

a. Dekonsentrasi wewenang administratif

b. Delegasi kepada penguasa otorita

c. Devolusi kepada pemerintah daerah 
d. Pemindahan fungsi dari pemerintah kepada swasta

Selanjutnya, desentralisasi merupakan teori pemerintahan yang rasional, yang kemudian diungkapkan dalam 14 alasan berikut (Syaukani, 2002):

a. Desentralisasi ditempuh untuk mengatasi keterbatasan karena perencanaan pembangunan yang bersifat sentralistik

b. Desentralisasi dapat memotong jalur birokrasi yang rumit serta prosedur yang terstruktur dari pemerintah pusat

c. Desentralisasi memberikan fungsi yang dapat meningkatkan pemahaman pejabat daerah atas pelayanan publik yang diemban

d. Desentralisasi akan mengakibatkan terjadinya penetrasi yang lebih baik dari pemerintah pusat bagi daerah terpencil, di mana rencana pemerintah seringkali tidak dipahami oleh masyarakat setempat atau bahkan dihambat oleh elit lokal

e. Desentralisasi memungkinkan representasi yang lebih luas dari berbagai kelompok politik, etnis, keagamaan dalam perencanaan pembangunan

f. Desentralisasi dapat meningkatkan kemampuan maupun kapasitas pemerintahan serta lembaga privat di daerah

g. Desentralisasi dapat meningkatkan efisiensi pemerintahan di pusat dengan tidak lagi mereka menjalankan tugas rutin

h. Desentralisasi dapat menyediakan struktur di mana berbagai departemen di pusat dapat dikoordinasikan secara efektif bersama dengan pejabat daerah dan sejumlah NGO i. Desentralisasi digunakan untuk melembagakan partisipasi masyarakat dalam perencanaan dan implementasi program

j. Desentralisasi dapat meningkatkan pengaruh atau pengawasan berbagai aktifitas yang dilakukan elit lokal yang kerap tak simpatik dengan programprogram pembangunan

k. Desentralisasi dapat mengantarkan pada administrasi pemerintahan yang mudah disesuaikan, inovatif dan kreatif.

1. Desentralisasi perencanaan dan fungsi manajemen memungkinkan pemimpin daerah menetapkan pelayanan secara efektif di tengah masyarakt terisolasi

m. Desentralisasi dapat memantapkan stabilitas politik dan kesatuan nasional dengan memberikan peluang kepada berbagai kelompok masyarakat di daerah

n. Desentralisasi dapat meningkatkan penyediaan barang dan jasa di tingkat lokal dengan biaya yang lebih rendah.

Mawhood (1987) mengungkapkan bahwa tujuan utama dari desentralisasi adalah sebagai upaya mewujudkan keseimbangan politik, akuntabilitas pemerintah lokal, dan pertanggungjawaban pemerintah lokal. Persayaratan tersebut kemudian diperkuat oleh Koirudin (2005) yang menjelaskan syarat-syarat agar tujuan tersebut dapat tercapai dengan mengkontekskan Indonesia. Persayaratan tersebut adalah pemerintah harus memiliki territorial kekuasaan yang jelas, memiliki Pendapatan Asli Daerah (PAD), memiliki badan perwakilan yang mampu mengontrol eksekutif daerah, dan adanya kepala daerah yang dipilih oleh masyarakat.

Dengan melihat beberapa persyaratan tersebut, maka dapat dikatakan bahwa 
desentralisasi tidak dapat berdiri sendiri.Hal ini diperkuat dengan pendapat Kingsley (1996) yang mengungkapkan bahwa desentralisasi hendaknya tidak dipandang sebagai suatu tujuan dengan sendirinya, melainkan alat untuk mencapai sistem-sistem pelayanan yang efektif.Selain itu, Koswara (2000) menyatakan bahwa hampir setiap negara bangsa (nation state) menganut desentralisasi sebagai suatu asas dalam penyelenggaraan pemerintahan negaranya.Dengan demikian, desentralisasi dapat digunakan untuk memenuhi tuntutan kelompok minoritas yang menuntut otonomi dalam wilayahnya.

Tentunya, apabila melihat tujuan dari adanya desentralisasi dan otonomi adalah bagaimana daerah diharapkan dapat meningkatkan pelayanan dan kesejahteraan masyarakat di daerah tersebut.Peningkatan pelayanan dan kesejahteraan tersebut kemudian didukung dengan adanya pelaksanaan demokrasi di daerah.Hal tersebut bertujuan agar daerah dapat mengatur dan mengurus daerah sesuai dengan kebutuhan maupun permintaan dari masyarakat daerah tersebut.Hal ini kemudian yang dimanfaatkan oleh elit daerah, baik yang berasal dari orang kuat lokal di luar pemerintahan maupun elit lokal di lembaga formal.Oleh karena ruang publik itu tidak dapat lepas dari kontestasi dan konstelasi dari aktor-aktor yang ada, maka yang terjadi adalah kekuatan-kekuatan yang saling bertarung dan berusaha menempatkan dirinya sebagai publik.Hal tersebut agar aktor-aktor atau kelompok tersebut dapat menjadi elit daerah dan menguasai sumber daya maupun mempertahankan kekuasaan sebagai elit daerah.

\section{PEMBAHASAN}

Menguatnya "orang kuat lokal" pada era desentralisasi dan otonomi daerah

Pergeseran dari fase sistem yang terpusat menjadi sistem otonomi daerah berdampak kepada menurunnya peran negara, dalam hal ini pemerintah pusat, terhadap daerah. Penguasa daerahberupaya untuk mempertahankan kekuasaannya tanpa bersandar lagi kepada pemerintah pusat. Penguasaan terhadap sumber daya yang ada berpotensi untuk mempertahankan kekuasaannya. Potensi tersebut dapat terwujud apabila sumber daya yang ada dapat dikendalikan dan diberdayakan. Di sisi lain, demokrasi dengan berisikan multi partai dan melalui proses pemilihan secara langsung tidak lagi membatasi setiap orang untuk ikut maju dalam pemilukada. Kedua hal tersebut yang kemudian menyebabkan terjadinya suatu pola relasi kekuasaan. Pola relasi kekuasaan tercipta dalam setiap kelompok masyarakat.

Setiap kelompok dalam masyarakat memiliki pemimpin yang bersifat otonom, dimana mereka memiliki modal sosial, terlepas dari intervensi negara. Hal tersebut yang kemudian membuat mereka bisa mengatur danmenerapkan the game conflict. Setelah reformasi, terjadi penguatan dalam masyarakat yang membuat peran negara berkurang. Pemimpin atau local strongman mulai mengambil peran dalam kekuasaan di level lokal. Migdal (2005) menyebutkan strategi triangle of accommodationsebagai strategi local strongmen dalam bertahan. Triangle of accommodationmerupakan kolaborasi antara local strongmen, negara, dan partai politik pemerintah. Oleh karena peran negara yang melemah, local strongmen sukses menguasai posisi dalam alokasi sumber daya. Mereka sukses menguasai dan memastikan alokasi sumber daya karena pengaruh mereka, bukan karena aturan resmi. Hal tersebut dikarenakan keberlangsungan local 
strongmen juga bergantung kepadakapasitas negara mengatur kontrol kepada mereka. Dengan demikian, Kehadiran strongmen merupakan refleksi dari kuatnya masyarakat.

Disamping pendekatan lokal strongmennya Migdal, elit lokal dapat dijelaskan melalui pendekatan local bossism yang dikemukakan oleh Sidel. Konsep local bossism merujuk kepada penguasaan atas sumber daya ekonomi dan kekerasan dalam suatu wilayah. Eksistensi dan keberlangsungan local bossism merupakan suatu refleksi kekuatan negara. Hal tersebut dikarenakan posisi negara yang kuat dalam teori bosisme.Local bossism mempertahankan kekuasaannya dengan cara berkolaborasi dengan negara dan partai politik. Mereka membutuhkan pejabat birokrasi untuk mempertahankan relasi kekuasaan dengan para elite penyelenggara negara. Kolaborasi local bossism tersebut dengan cara melakukan stationary bandit dan rowing bandit.Local bossism inilah yang kemudian memanipulasi negara sehingga memiliki kekuatan dan mampu melakukan penetrasi ke dalam masyarakat, mengatur relasi sosial, dan mengeksploitasi sumber daya alam. Sebaliknya, mereka memberikan jasa dalam memobilisasi dukungan dengan cara mengintimidasi pemilih yang membuat mereka memperoleh akses ekonomi. Local bossism yang dikemukakan oleh Sidel (1999) memberikan perspektif tentang bagaimana jaringan orang kuat itu menguasai, memperkuat dan memanfaatkan negara untuk kepentingannya. Ciri predatoris negara pada bossism merupakan konsekuensi untuk menciptakan negara kuat dari jaringan para bos.

Dari pendekatan lokal strongmen-nya Migdal dan local bossism yang dikemukakan oleh Sidel, ditemukan beberapa perbedaan sebagai berikut :

\section{Tabel 1. Perbedaan pendekatan lokal strongmen -nya Migdal dan local bossism yang dikemukakan oleh Sidel}

\begin{tabular}{ccc}
\cline { 2 - 3 } Sumber legitimasi & $\begin{array}{c}\text { Local Strongmen } \\
\text { (Migdal) }\end{array}$ & $\begin{array}{c}\text { Local Bossism } \\
\text { (Sidel) }\end{array}$ \\
\cline { 2 - 3 } & Figuritas dan mistis & $\begin{array}{c}\text { Figuritas dan } \\
\text { ketakutan }\end{array}$ \\
\hline Posisi negara & lemah & kuat \\
\hline Alasan terbentuk & Struktur masyarakat & $\begin{array}{c}\text { diciptakan atau } \\
\text { dilindungi negara }\end{array}$ \\
\hline aktor & $\begin{array}{c}\text { Tuan tanah, orang } \\
\text { kaya, pemimpin } \\
\text { tradisional. }\end{array}$ & $\begin{array}{c}\text { pengusaha, orang } \\
\text { kaya, preman. }\end{array}$ \\
\hline
\end{tabular}

Selain konsep local bossism yang merujuk kepada penguasaan atas sumber daya ekonomi dan kekerasan dalam suatu wilayah, Sidel (2005) juga mengungkapkan transisi demokrasi setelah adanya reformasi makin memperlebar kemungkinan akumulasi kekuasaan local strongmen oleh mafia dan jaringan marga. Demokratisasi di ranah lokal melalui desentralisasi dan otonomi daerah, ternyata banyak dimanfaatkan oleh bos lokal untuk merengkuh kekuasaan dengan memveto kekerasan di dalam ruang publik. Hal tersebut dapat dilihat dari relasi politik lokal antara jawara dan penguasa politik lokal di Banten, dimana semakin dominannya local bossism menjadi local stongmen.Hal tersebut terjadi dikarenakan adanya kecenderungan reorganisasi kekuasaan dari kelompok 
oligarki, yang mengusai jaringan sosial ekonomi dan politik lokal untuk kepentingan mereka sendiri. Akumulasi kekuasaan local strongmen oleh local bossismdari kelompok oligarki mempunyai beberapa kecenderungan. Pertama, tidak memberi kesempatan orang lain melakukan kritik terhadap kekuasaannya. Kedua,ketika ada elite yang potensial menyaingi kekuasaannya mereka berusaha untuk menghalangiatau membunuh karier politiknya. Ketiga, jalan kekerasandilakukan dalam mempertahankan kekuasaannya. Dengan demikian, kekuasaan local strongmen yang berlatarbelakang sebagai local bossismdari kelompok oligarkiakan berusaha didapatkan, dijalankan dan dipertahankan kekuasaan tersebut dengan berbagai cara.

Dengan demikian, terdapat pembilahan terkait yang dimaksud dengan elit lokal.Elit lokal yang berasal dari luar lembaga (informal) atau dari dalam lembaga formal pemerintah.Artinya, pembilahan ini masih berdasarkan pada asal aktor.Akan tetapi, hal tersebut belum dapat menggambarkan elit lokal saat terjadi persebaran kekuasaan di era demokrasi dan otonomi daerah.Hal tersebut dikarenakan terbukanya ruang dan politik nasional tidak lagi kental terhadap kondisi politik di daerah.

\section{Elit Daerah: Ruang Yang Terbuka Dan Bersifat Sentrifugal}

Keberadaan elit dalam suatu struktur masyarakat menjadi keniscayaan. Struktursosial tidak pernah terlepas dari lapis relasi yang hirarkis antara sekelompok kecil orang menguasai sumber daya dan mereka yang tidak memiliki kapasitas untuk menguasainya. Kondisi ini dimungkinkan oleh kompleksitas ruang sosial yang memungkinkan terkonsentrasinya setiap keputusan di tangan segelintir orang. Dari sanalah elit itu terbentuk ketika dengan legitimiasi yang dibangun berusaha untuk mempengaruhi setiap keputusan politik (Higley, 2010).

Elit sebagai suatu fakta sosial selalu dijelaskan dalam penekanan yang beragam. Mosca menitik beratkan pada sekelompok minoritas yang menguasai mayoritas masyarakat (ruling class over ruled class), Pareto melihat pada governing elit, governing elit ini pun memiliki kekhasan dalam mengoperasikan kekuasaan yakni melalui pendekatan Foxes (kecerdikan) dan Lion (kekerasan). Sedangkan Wright Mills menitik beratkan pada relasi antara berbagai elit dalam suatu masyarakat untuk membentuk kekuasaan elit.Terlepas dari setiap perbedaan, teorisasi mengenai elit sepakat dengan penjelasan ontologis yang mendefinisikan elit sebagai aktor-aktor yang berdasarkan pada posisi strategis atau sangat penting dalam organisasi maupun suatu gerakan besar, dapat mempengaruhi hasil politik secara teratur dan juga secara substansial (Higley, 2010).

Definisi di atas memberi batasan sepesifik terhadap penjelasan mengenai elit yakni orang atau sekelompok orang yang memiliki pengaruh politis yang bersifat reguler dan substansial. Pengaruh ini diperoleh karena kemapuannya sehingga elit memiliki legitimasi untuk bertindak. Lebih lanjut, apabilamengamati eksplanasi teoritis Mosca dan Pareto, atau Mills, dapat berkesimpulan bahwa mereka cenderung melihat elit yang konsolidatif.Hal tersebut tentunya tidak dapat digeneralisasikan mengingat terdapatnya keterbukaan ruang dan aktor sehingga kekuasaan dan konflik cenderung untuk tidak lagi terpusat.Penjelasan yang cenderung melihat elit yang konsolidatif tersebut gagal menangkap realitas keterbelahan elit. Tersebarnya kekuatan-kekuatan politis menjadikan formasi elit yang terbentuk pun bersifat sentrifugal. Artinya, banyak titik 
kordinat yang saling konfliktual untuk memiliki pengaruh yang sama dalam suatu masyarakat.

Dengan demikian, realitas keterbelahan elit di era demokrasi dan otonomi daerah semakin mengaburkan posisi elit.Tentunya, hal ini kemudian dapat menegasikan elit sebagai suatu keterpusatan atau berkaitan dengan monopoli sumber daya yang tunggal.Tentunya, ada persebaran sumber daya yang kemudian dimiliki oleh beberapa kelompok aktor.Hal tersebut kemudian dapat menggambarkan terjadi persebaran kekuasaan.Artinya, terkait dengan tujuan dari demokrasi dan otonomi yakni adanya keterbukaan ruang, maka demokrasi dan otonomi dapat diartikan.Akan tetapi, keterbukaan ruang tersebut kemudian memiliki kelemahan yakni konflik cenderung lebih sulit terlesaikan dikarenakan semakin banyak aktor yang berkuasa sebagai elit lokal.

\section{KESIMPULAN}

Desentralisasi dan otonomi daerah diharapkan sejalan dengan konsep demokrasi pemerintahan, yakni pelimpahan sebagian wewenang yang dimiliki pemerintah pusat terhadap pemerintah daerah.Dalam hal ini pemerintah daerah berkewajiban untuk melaksanakan wewenang sesuai dengan kehendak dan inisiatif sendiri.Tentunya, apabila melihat tujuan dari adanya desentralisasi dan otonomi adalah bagaimana daerah diharapkan dapat meningkatkan pelayanan dan kesejahteraan masyarakat di daerah tersebut.Peningkatan pelayanan dan kesejahteraan tersebut kemudian didukung dengan adanya pelaksanaan demokrasi di daerah.Hal tersebut kemudian yang dimanfaatkan oleh elit daerah, baik yang berasal dari orang kuat lokal di luar pemerintahan maupun elit lokal di lembaga formal.Oleh karena ruang publik itu tidak dapat lepas dari kontestasi dan konstelasi dari aktor-aktor yang ada, maka yang terjadi adalah kekuatan-kekuatan yang saling bertarung dan berusaha menempatkan dirinya sebagai publik.

Pada saat daerah belum melaksanakan otonomi dan demokrasi lokal, maka yang terjadi adalah elit lokal cenderung derivasi dari politik nasional sehingga pada saat terjadi konflik lokal maka penyelesaian konflik dapat lebih mudah terselesaikan.Akan tetapi, hal tersebut tentunya tidak dapat digeneralisasikan mengingat terdapatnya keterbukaan ruang dan aktor sehingga kekuasaan dan konflik cenderung untuk tidak lagi terpusat.Elitmemiliki pengaruh politis yang bersifat reguler dan substansial. Pengaruh ini diperoleh karena kemapuannya sehingga elit memiliki legitimasi untuk bertindak. Meskipun demikian, penjelasan tersebut gagal menangkap realitas keterbelahan elit maupun bersifat multipolar. Tersebarnya kekuatan-kekuatan politis menjadikan formasi elit yang terbentukkemudian bersifat sentrifugal. Dengan demikian, terdapat banyak titik kordinat yang saling konfliktual untuk memiliki pengaruh yang sama dalam suatu masyarakat.

\section{DAFTAR PUSTAKA}

Higley, J. (2010). Elite Theory and Elites. In K. T. Leicht, \& J. C. Jenkins, Handbook of Global Politics. New York: Springer.

Kingsley, T. (1996). Perspective on Devolution. Journal of The American Planning Association Volume 62, No.4 .

Koirudin. (2005). Sketsa Kebijakan Desentralisasi di Indonesia: Format Masa Depan Otonomi Menuju Kemandirian Daerah. Malang: Averroes Press.

Koswara. (2000). Makna Otonomi Daerah. Jakarta: Jurnal Ilmu Pemerintahan -

PUBLISIA (Jurnal Ilmu Administrasi Publik) | 51 
Masyarakat Ilmu Pemerintahan Indonesia (MIPI).

Mawhood, P. (1987). Local Government in the Third World. John Wiley and Son.

Migdal, J. \&. (2005). Rethinking the State. In K. Schlichte, The dynamics of state: the formation and crises of the state domination. Burlington: Ashgate.

Mills, C. W. (2000). The Power Elite. Oxford University Press.

Mosca, G. (1939). The Ruling Class. New York: McGraw - Hill.

Pareto, V. (1935). The Mind and Society: A Treatise On General Sociology. New York: Dover.

Sidel, J. T. (2005). Bosisme dan Demokrasi di Filipina, Thailand dan Indonesia; Menuju Kerangka Analisis Baru Tentang Orang Kuat Lokal. In J. Harriss, Politisasi Demokrasi Politik Lokal Baru. Jakarta: Demos.

Sidel, J. T. (1999). Capital, Coercion, and Crime: Bossism in The Philippines. Stanford: Stanford University Press.

Syaukani, H., Gaffar, A., \& Rasyid, R. (2002). Otonomi Daerah dalam Negara Kesatuan. Yogyakarta: Pustaka Pelajar. 